\title{
梁端部の脆性破壊を伴う鋼構造骨組の地震応答 \\ SEISMIC RESPONSE OF STEEL FRAMES INCLUDING BRITTLE FRACTURES AT BEAM-ENDS
}

\author{
上谷宏二*, 田川 浩** \\ Koji UETANI and Hiroshi TAGAWA
}

\begin{abstract}
After the Hyogoken Nambu Earthquake, January 17, 1995 and the Northridge Earthquake, January 17, 1994, fracture behavior was observed in many steel buildings at their welded connections between beams and columns, structural members and other structural components. In earthquake-resistant design criteria of buildings, plastic deformations are permitted to absorb the seismic energy, while fractures are unacceptable. Therefore the response properties of a frame which undergoes fracture type collapse behavior have not been investigated. It is necessary to investigate the response properties in order to evaluate the earthquake resistance capacity of a frame taking account of the possibility of brittle fractures. In this paper, seismic response analyses, considering the effects of brittle fractures at beam-ends during an earthquake excitation, are carried out for steel frames. The response properties are compared to those of ductile frames and the effects of fractures on the seismic response of steel frames are discussed.
\end{abstract}

Keywords : steel structure, brittle fracture, seismic response analysis beam-to-column connection, energy response

鋼構造，脆性破壊，地震応答解析，柱梁接合部，エネルギー応答

\section{1. 序}

1995年1月に発生した兵庫県南部地震扔よび1994年1 月に発生した米国ノースリッジ地震による鋼構造骨組 の被害で、柱梁接合部の溶接部や梁端部フランジなど

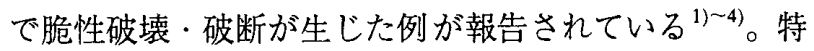
徵的であることは、複数の部位で破断が生じているに もかかわらず外観からは被害が観察されなかった骨組 が多数存在することである。通常の設計では、部材が 破断することなく塑性変形するという仮定の下で、地 震外乱等水平力作用時の部材断面応力ゃ骨組变形量の 検定を行っている。応答中に生じる部材破断が骨組応 答に及ぼす影響は検討していないので、多数の骨組で 破断を生じたにもかかわらず外観から観察されない程 度の被害で済んだ理由は的確に把握できていない。ま た一方では、地震動特性などの条件が異なれば、異な る地震外乱下では、部材の破断が被害を拡大させる要 因となる可能性があることも否定できない。

これまでに、部材破断が生じる原因や破断が生じる
骨組の応答特性を解明しようとする研究が多数なされ ている。例えば、実際に被害を受けた建物のモデル骨 組に記録地震動を入力したときの応答について、設計 通り塑性変形する場合の数值解析を行い、部材の塑性 率等を求め、その值と実際に破断した部位の対応を調 べた研究がある 5)。。別の研究では、ある骨組について 破断が生じると想定した部位に予めヒンジ（軸力およ びせん断力を伝達するが曲げモーメントは伝達しない） を設けて地震応答解析を行い、初めの骨組の地震応答 とどのように異なるかを調べたものなどがある1”。

一方、応答中に部材の破断が生じることを考慮して 応答特性等を調べた研究としては、せん断型モデル骨 組において柱に脆性破壊が生じるときの応答特性を調 べた研究7)等があるが、極めて少ない。その理由として は、脆性破壊の発生には大きなばらつきがあるため破 壊条件の設定が困難なこと、破壊した要素が破壊後呈 する挙動特性が明確でないことなどが挙げられる。し かし、脆性破䧇を伴う鋼構造骨組の地震応答特性を明

\footnotetext{
本論文の一部は，文献24)で発表されている。 * 京都大学大学院工学研究科建築学尃攻 教授・工博

** 京都大学大学院工学研究科建築学専攻 助手・工修
}

Prof., Dept. of Architecture and Architectural Systems, Graduate School of Engineering, Kyoto Univ., Dr. Eng.

Research Assoc., Dept. of Architecture and Architectural Systems, Graduate School of Engineering, Kyoto Univ., M. Eng. 
らかにすることは、耐震設計をより合理的に行うため にも重要であろう。また、既存の鋼構造骨組に対して 脆性破壊に対する効果的な補強方法を考える際の基礎 資料になると思われる。

本論文では、脆性破罗を伴う骨組の基本的特性を明 らかにすることを目的として、破断要素モデルとして 代表的なものを想定し、その破断要素モデルが組み込 まれた骨組モデルの動的応答を的確に追跡できる数值 解析法を構築する。構築した数值解析法を用いて、破 断を伴う銅構造骨租の地震応答を追跡し、応答特性を 明らかにする。その際、十分塑性変形し破断が生じな い場合の応答と比較しながら、破断が变形応答やエネ ルギー応答に及ほす影響を考察する。兵庫県南部地震 およびノースリッジ地震では、10層程度の鋼構造骨組 において、多数の梁端部で脆性破壊が生じたが柱端部 ではほとんど脆性破壊が生じず、外観からは被害が観 察されなかった骨組が多数存在した。そこで数値解析 では、梁端部の破壊が応答に及はす影響を解明するこ とを目的として、脆性破壊する部位を梁端部に限定し た10層3スパン鋼構造骨組を对象とする。

\section{2.脆性破壊を伴う多層多スパン鋼構造骨組の動的応}

\section{答数值解析法}

2. 1 解析骨組モデル

図 1 に示す多層多スパン純ラーメン平面骨組を考え る。質量が節点（柱梁接合部）に集中して存在する。 各質量による鉛直荷重は柱軸力として考慮する。

\section{2 解析方法}

梁部材は曲げ変形のみを考え、軸方向変形拉よびせ ん断変形は無視する。柱部材は曲げ変形および軸方向 変形を考慮し、せん断変形は無視する。柱部材の曲げ 変形に対してはP- $\Delta$ 効果を考慮するため、座屈撓角法 ${ }^{8)}$ に基づく剛性行列を用いる。各質量に生じる慣性力は 水平成分のみ考虑し、鉛直扔よび回転方向の変位拉よ び速度は静的縮約する。また、同一層の質量の水平変 位は等しいとする。よって、各層の運動に関する自由 度は水平方向の 1 自由度となる。系剛性行列が一定の 増分区間の運動方程式をモード分解して厳正解を求め、 增分解を質点の变位と速度の連続条件を用いて接続す る。運動方程式の解析にはNigam-Jennings法りを用いる。 粘性減衰力を想定し、初期の固有振動数に比例する減 衰定数を運動中各次モードに対し固定して使用する。

\section{3 破断要素モデル}

鋼部材の終局挙動や脆性破壊については数多くの研 究 $^{10)-21)}$ がなされ、その力学的特性が次第に明らかにさ れつつあるが、破断に至るまでの塑性変形量には大き

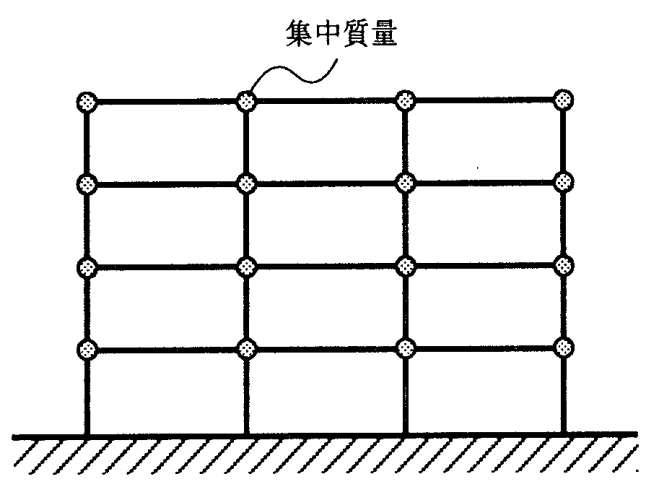

図 1 骨組モデル
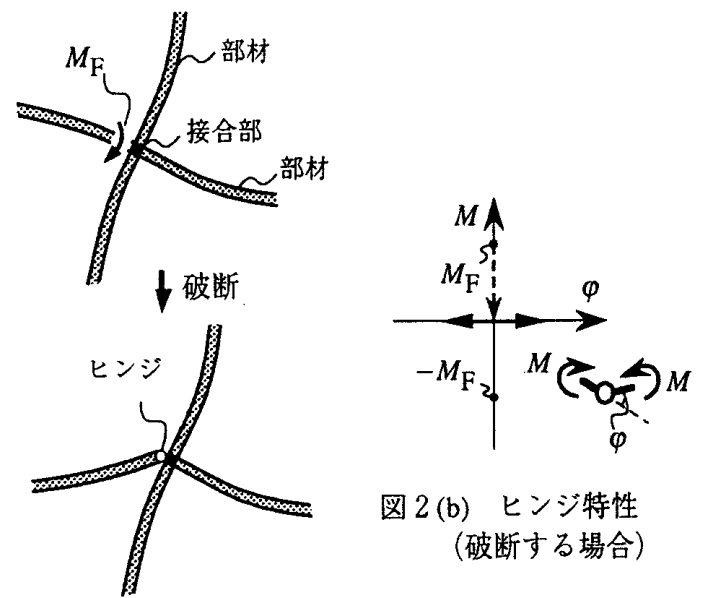

図 2 (b) ヒンジ特性 (破断する場合)

図 2 (a) 破断要素モデル
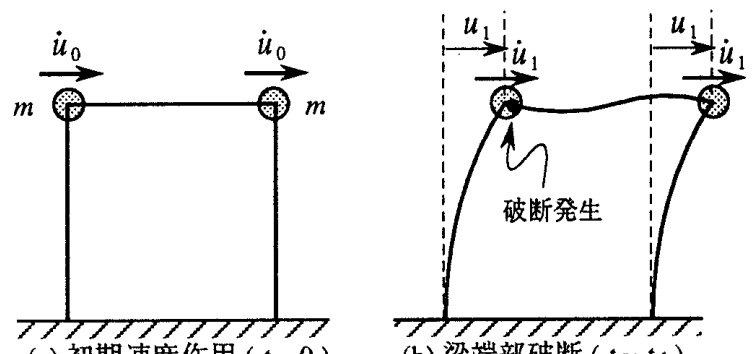

(a) 初期速度作用 $(t=0)$
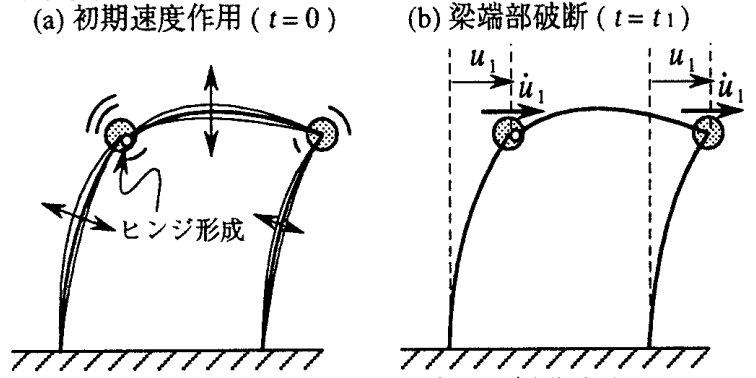

(c) 破断時高周波振動

(d) 高周波振動消滅 $(t=t+\Delta t)$

図 3 破断直後の骨組挙動の仮定

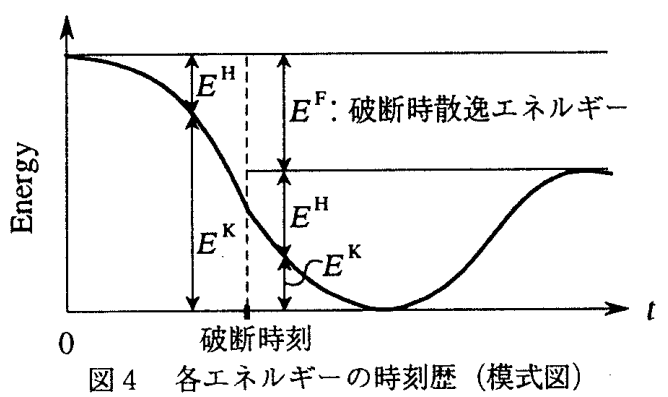


なばらつきがあり、破断条件を特定することは困難で ある。一方、被害調查で明らかになっている破断形式 には、ノースリッジ地震で多く見られた弾性域から破 断するタイプ゚1),2) 户兵庫県南部地震で多く見られたある 程度塑性変形した後に破断するタイプ忽,4)がある。また、 破断が生じた部位は、スラブの合成効果により下フラ ンジが最も多いが、上フランジ・上下ダイアフラム。 ウェブ等での破断も見られ多様である ${ }^{4), 6 。 ~}$

したがって、破断条件や破断要素モデルを一意に定 めることは現実的でないが、本論文の目的は、破断を 伴う鋼構造骨組の地震応答の基本的特性を明らかにす ることであり、破断条件扔よび破断要素モデルには代 表的なものを取り上げる。ここでは、眓2(a)に示すよう に梁あるいは柱部材端部の曲げモーメントが破断モー メント $M_{\mathrm{F}}$ に達すると塑性変形することなく破断し、 破断した部材端部にモーメントを伝達しないヒンジが 形成されるモデルを想定する。ヒンジ特性を図2(b)に示 す。このモデルは、(a)塑性変形することなく破断する 点、(b)破断後に曲げ抵抗が 0 になる点、(c) 部材端部の 正・負曲げに依らず破断する点を考慮すると、破断要 素モデルとしては危険側のモデル化である。

今後、より現実に近い破断条件・破断要素モデルを 想定した研究が必要である。筆者らはこれまでに梁端 部下フランジのみの破断を想定した骨組の応答特性に 関して文献22)で報告している。

\section{4 破断直後の骨組挙動に対する仮定}

破断直後の骨組挙動に対して導入する仮定について、 図3(a)図に示す、接合点に質量 $m$ を有する門形ラーメン 骨組を用いて説明する。質量 $m$ に水平方向初期速度 $\dot{u}_{0}$ を作用させる。同(b)図に示すように時刻 $t=t_{1}$ に梁端部 に破断が生じる場合を想定する。破断直後、ヒンジ部 でモーメントの釣合が保たれなくなり同(c)図に示すよ うに各部材が高周波振動する。この振動は粘性減衰作 用により早期 $\left(t=t_{1}+\Delta t\right)$ に消滅する。そこで、この高 周波振動が瞬時に消滅し、破断と同時刻 $(\Delta t \rightarrow 0$ に相 当）に同(d)図に示す鉛直および回転方向の静的鈞合状 態に達すると仮定する期注)。これは、鉛直・回転方向の 運動を静的縮約することに対応する。この仮定の下で は破断前後で接合点の水平変位 $u_{1}$ と速度 $\dot{u}_{1}$ は連続とな るが、鉛直変位、回転角とそれらの速度は不連続とな る。な扔、本数值解析法では、高周波振動を追跡しな い等の理由により、解析時間を非常に短くできる。

鉂注) 筆者らは、破断時に高周波振動が発生しそれが早期に消 滅する応答を、コンシステント質量行列を用いて全自由度の 慣性力を考虑した数值解析により追跡した。その結果と本数 值解析結果を比較し、導入寸る仮定の正当性を確認した
次に、図3に示した骨組挙動に関して、エネルギー応 答を図4に模式的に示す。運動エネルギーを $E^{\mathrm{K}}$ 、内部 エネルギー（ここでは弾性ひずみエネルギー）を $E^{\mathrm{H}}$ で 表す。破断の直後に発生する高周波振動は、仮定より 瞬時に減衰し消滅する。この場合、破断時刻において、 水平方向速度は連続であるため運動エネルギーは連続 となるが、内部エネルギーは一部が消滅し、振動エネ ルギー $E^{\mathrm{K}}+E^{\mathrm{H}}$ が減少する。この消滅したエネルギーを 破断時散逸エネルギー $E^{\mathrm{F}}$ と定義する。な挍、破断時に は破断面の形成のためにエネルギーが消費される。本 論文ではこの消費エネルギーの評価は行わないが、破 断時散逸エネルギー $E^{\mathrm{F}}$ に含まれるものである。

\section{3. 地震応答解析}

構筑した数值解析法を用いて、梁端部のみが脆性破 壊する10層3スパン骨組の地震応答解析を行い、応答特 性を明らかにする。このとき梁端部が十分塑性変形し 破断しない場合の解析も平行して行い応答を比較する。

\section{1 解析骨組}

図5に示す10層3スパン平面骨組を考える。階高は全 層 $3 \mathrm{~m}$ 、スパン長は全て $6 \mathrm{~m}$ である。質量は節点（柱梁接 合部）に集中させ全て20tonとする。柱は弾性を保持す ると仮定する。また、梁端部の破断モーメント $M_{\mathrm{F}}$ は 降伏モーメント $M_{\mathrm{Y}}$ と等しい場合を想定する。柱部材 （C1〜C4）扔よび梁部材（G1〜G4）の断面諸量を表 1 に示す。ヤング係数は 2100 tonf $/ \mathrm{cm}^{2}$ とする。解析骨組の 1 次固有周期は 1.007 秒、 2 次は 0.357 秒である。減衰定 数は 1 次固有振動に対して0.02とする。

比較するため、破断が生じない場合の解析も行うが、 この場合は梁端部に塑性ヒンジが形成されると仮定す る。塑性ヒンジ特性は図6に示すバイリニア型とし、勾 配 $k^{\mathrm{P}}$ は、梁部材の逆対称塑性曲げ変形時の復元力の勾 配が弾性勾配の1/100となるように設定する。

\section{2 入力地震動}

入力地震動には、El Centro 1940 NS, Hachinohe 1968 NS, Kobe 1995 NS（神戸海洋気象台）の各波形を最大速 度振幅が $50 \mathrm{~cm} / \mathrm{sec}$ となるように基準化して用いる。入力 地震動の継続時間はいずれも20秒とする。

\section{3 解析結果}

\section{3.1 塑性ヒンジ・破断発生部位}

図7-1〜7-3に、塑性ヒンジが形成した部位扔よび破断 が生じた部位を○で示す。各数字は次式に示す $\mu$ の値 を表す。これは破断しない場合には塑性率となる。

$$
\mu=\frac{\theta_{\mathrm{Y}}+\varphi_{\max }}{\theta_{\mathrm{Y}}}
$$

ここに、 $\varphi_{\max }$ は破断しない場合は最大塑性ヒンジ回 転角、破断する場合は最大ヒンジ回転角を表し、 $\theta_{\mathrm{Y}}$ 


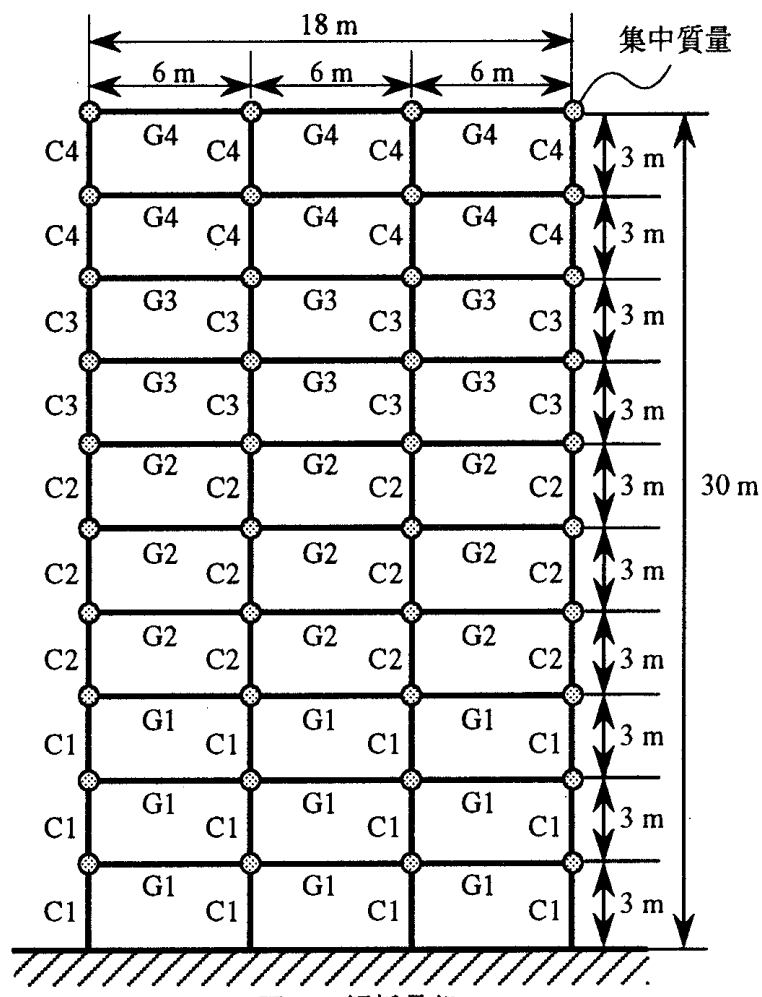

図 5 解析骨組

表 1 部材断面諸量

\begin{tabular}{|c|c|c|c|c|}
\hline & $\begin{array}{l}\text { 断面 } 2 \text { 次モー } \\
\text { メント }\left(\mathrm{cm}^{4}\right)\end{array}$ & $\begin{array}{l}\text { 降伏 (破断) モーメ } \\
\text { ント (tonf } \cdot \mathrm{cm})\end{array}$ & $\begin{array}{l}\text { 断面積 } \\
\left(\mathrm{cm}^{2}\right)\end{array}$ \\
\hline \multirow{4}{*}{ 柱 } & C1 & 200000 & infinity & 400 \\
\hline & $\mathrm{C} 2$ & 160000 & infinity & 350 \\
\hline & $\mathrm{C} 3$ & 120000 & infinity & 300 \\
\hline & $\mathrm{C} 4$ & 80000 & infinity & 250 \\
\hline \multirow{4}{*}{ 梁 } & G1 & 150000 & 18000 & \\
\hline & $\mathrm{G} 2$ & 120000 & 15000 & \\
\hline & G3 & 90000 & 12000 & \\
\hline & G4 & 60000 & 9000 & \\
\hline
\end{tabular}

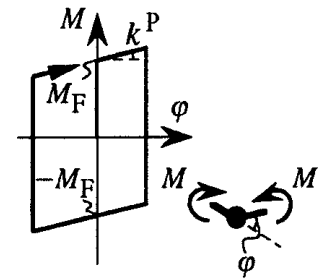

図 6 塑性ヒンジ特性 (破断しない場合)

は梁部材の逆対称曲げ変形時の降伏部材角を表す。 破断しない場合：HachinoheNS入力時にはほとんど塑性 変形しない。一方、ElCentroNS扔よびKobeNS入力時に は、最上層から数層を除くほほ全域に渡り塑性ヒンジ が形成されており、かつ塑性率分布に偏りが少ない。 破断する場合：ElCentroNS入力時には上層の 6 層、
HachinoheNS入力時には下層の 6 層、KobeNS入力時に は中間の 5 層に、それぞれ破断部位が集中している。 地震波により破断部位に相当の違いが見られる。また、 HachinoheNS入力時の破断しない場合と破断する場合を 比較すると、一度破断が生じるとそこに変形が集中し 破断部位が拡大していく性質があることが分かる。

\section{3. 2 最大層間変形角}

図8に最大層間変形角分布を示す。

破断しない場合：概ね0.01付近の值をとって扔り、良好 な変形分布であると言える。

破断する場合：破断が集中する数層に最大層間変形角 が偏って大きくなっており、最大值は0.03を超えている。

\section{3.3 最上層水平変位時刻歴}

図9-1 9-3に最上層の水平変位時刻歴曲線を示す。弾 性時の 1 次固有周期は約 1 秒であるが、破断する場合、 最終状態での 1 次固有周期はいずれのケースも長くな り、約 3 秒に達する。また、ElCentroNS入力時には、 破断する場合の振幅が破断しない場合よりかなり大き いのに対し、KobeNS入力時には両者の差は小さい。

\section{3.4 エネルギー応答}

地震外乱を受け弾塑性挙動する構造物に関して、次 式で表されるエネルギーバランスが成立する。

$$
E^{\mathrm{K}}+E^{\mathrm{D}}+E^{\mathrm{H}}=E^{\mathrm{I}}
$$

ここで、 $E^{\mathrm{K}}$ は運動エネルギー、 $E^{\mathrm{D}}$ は隇衰による散逸 エネルギー、 $E^{\mathrm{H}}$ は内部エネルギー、 $E^{\mathrm{I}}$ は入力エネル ギーを表す。内部エネルギー $E^{\mathrm{H}}$ は、部材の弾性ひずみ エネルギーと塑性変形に伴う履歴消費エネルギーの合 計である。入力エネルギー $E^{\mathrm{I}}$ は、地震によるものと自 重と鉛直方向変位によってなされるものの合計である。

一方、応答中に部材が破断する場合には、2、4節 で定義した破断時散逸エネルギー $E^{\mathrm{F}}$ を考慮して、エネ ルギーバランスを表す式は次式となる。

$$
E^{\mathrm{K}}+E^{\mathrm{D}}+E^{\mathrm{H}}+E^{\mathrm{F}}=E^{\mathrm{L}}
$$

図10-1〜10-3に、エネルギー応答を示す。破断する場合、 いずれの結果においても、入力エネルギー $E^{\mathrm{I}}$ に占める 破断時散逸エネルギー $E^{\mathrm{F}}$ の割合が大きいのが特徴的で ある。特に、E1CentroNSおよびKobeNS入力時は、破断 時散逸エネルギーが、破断しない場合の履歴消費エネ ルギーと同レベルに達している。また、20秒後の入力 エネルギーを比較すると、破断しない場合の值に対す る破断する場合の值の比は、EICentroNS入力時は1.2、 HachinoheNS入力時は2.1 と、破断する場合の方が大き くなるのに対し、KobeNS入力時は 0.65 と破断する場合 の方がかなり小さくなっている。この違いは、破断後 の入力エネルギーの変化の特性が、地震動によって大 きく異なることに起因している。 


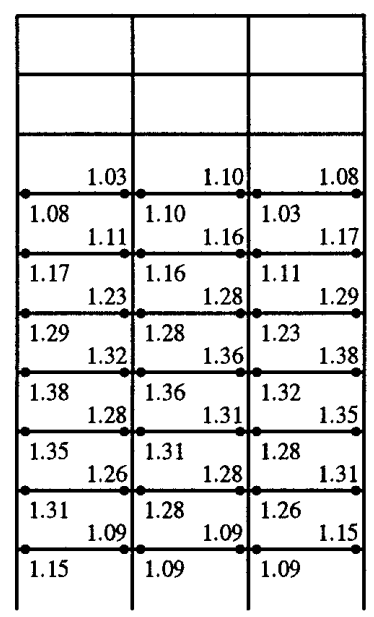

(a) 破断しない場合

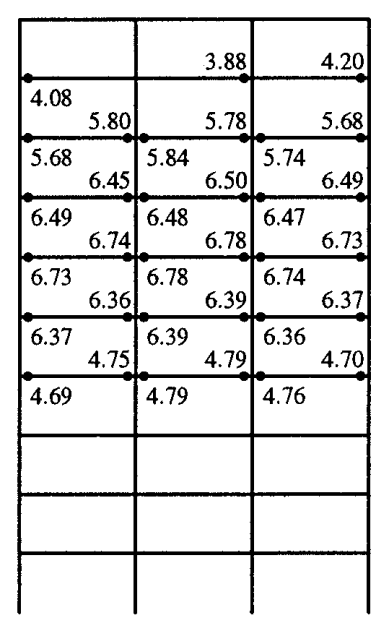

(b) 破断する場合

図7-1 塑性ヒンジ・破断発生部位 (El Centro NS 入力)

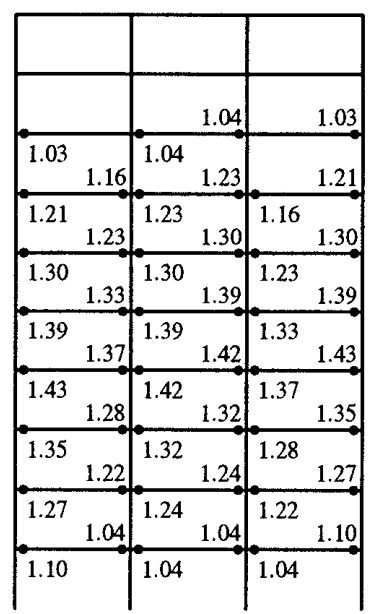

(a) 破断しない場合

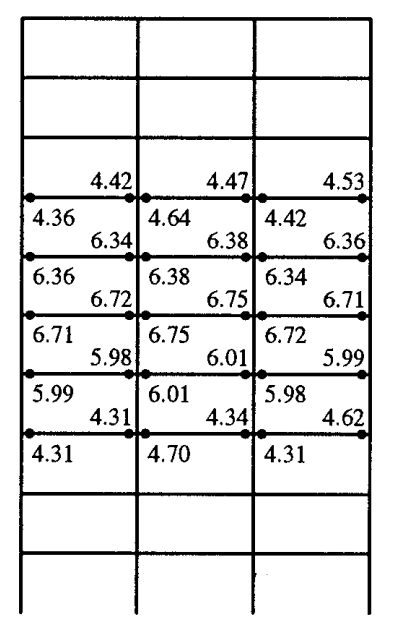

(b) 破断する場合

図7-3 塑性ヒンジ・破断発生部位 (Kobe NS 入力)

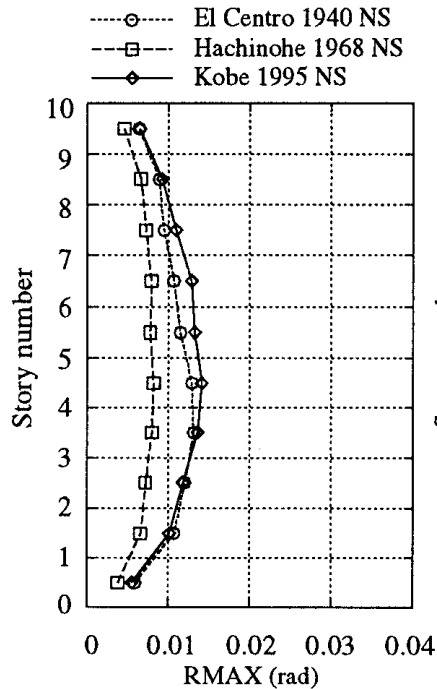

(a) 破断しない場合

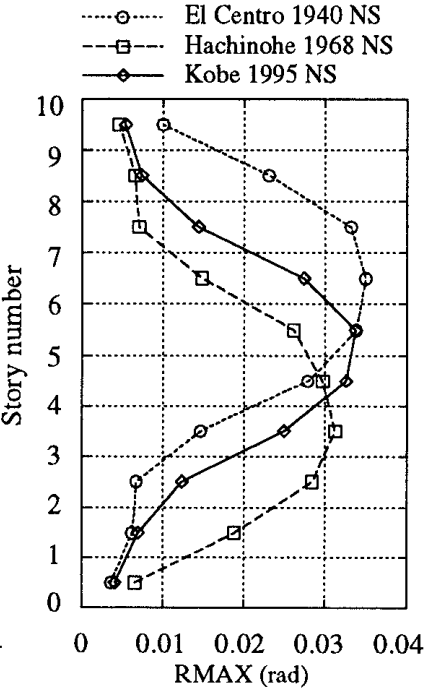

(b) 破断する場合

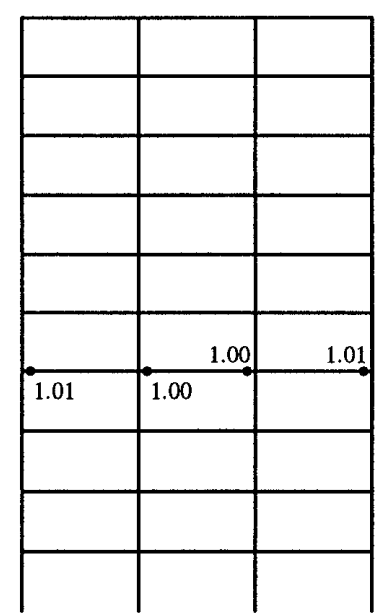

(a) 破断しない場合

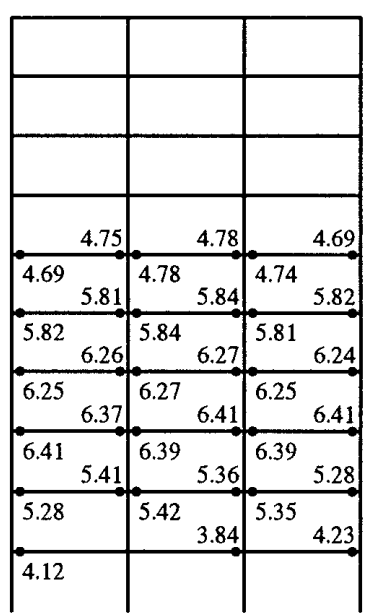

(b) 破断する場合
図7-2 塑性ヒンジ・破断発生部位 (Hachinohe NS 入力)

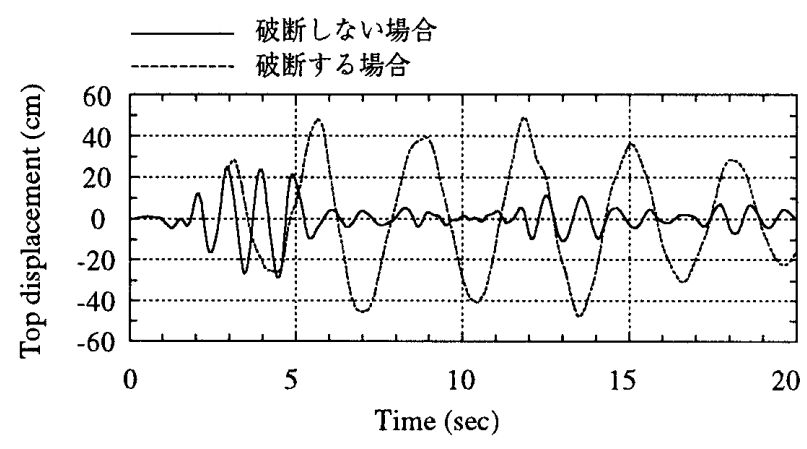

図9-1 最上層水平変位時刻歷 (El Centro 1940 NS 入力)

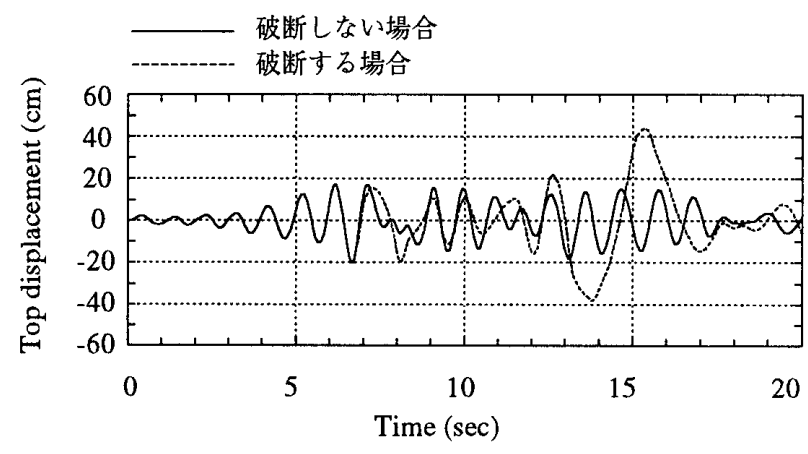

図9-2 最上層水平変位時刻歴 (Hachinohe 1968 NS 入力)

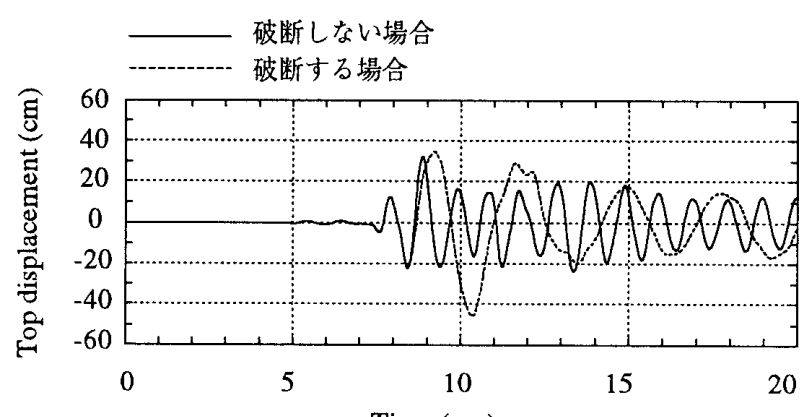

Time (sec)

図9-3 最上層水平変位時刻歷 (Kobe 1995 NS 入力) 


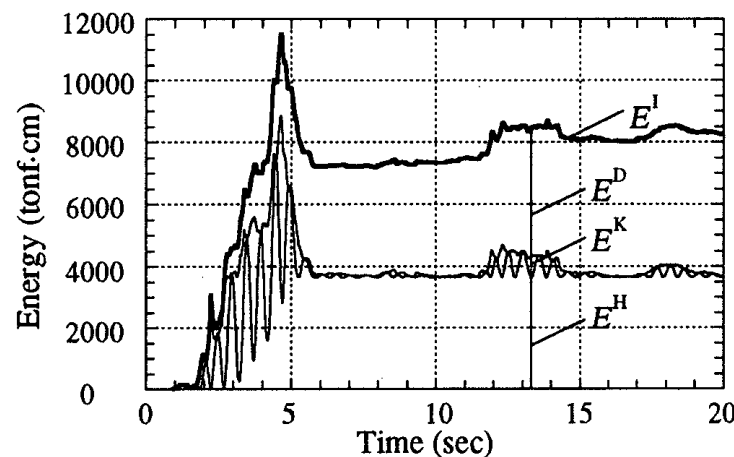

(a) 破断しない場合

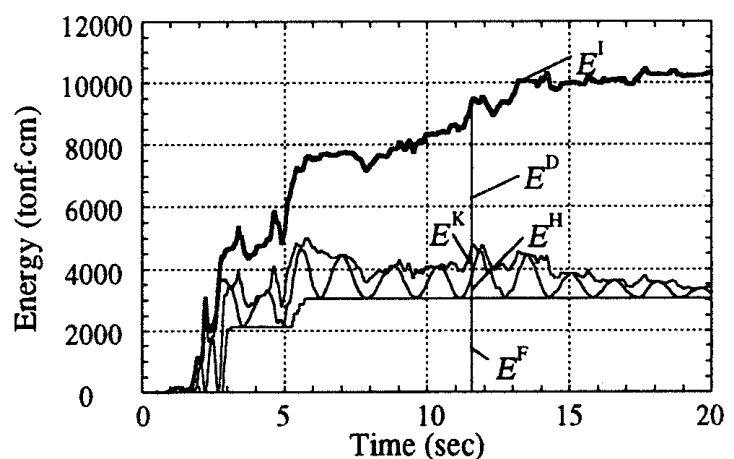

(b) 破断する場合

図10-1 各エネルギー時刻歴（El Centro 1940 NS 入力時）

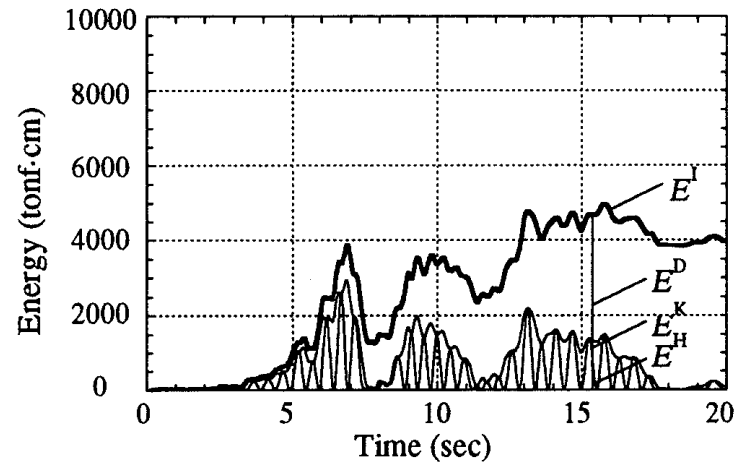

(a) 破断しない場合

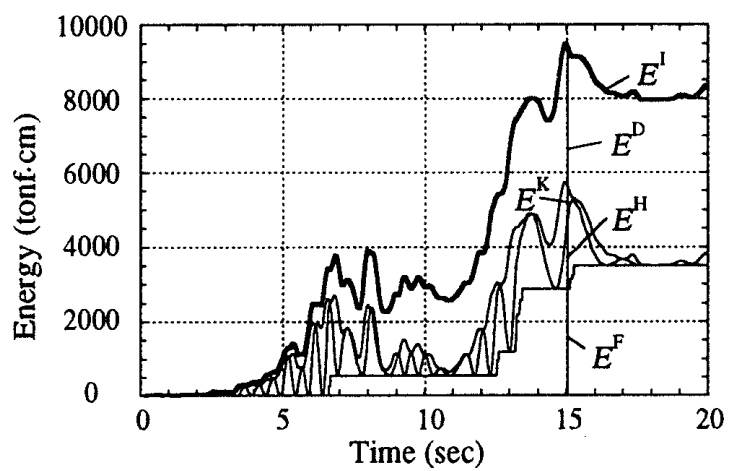

(b) 破断する場合

図10-2 各エネルギー時刻歴（Hachinohe 1968 NS 久力時）

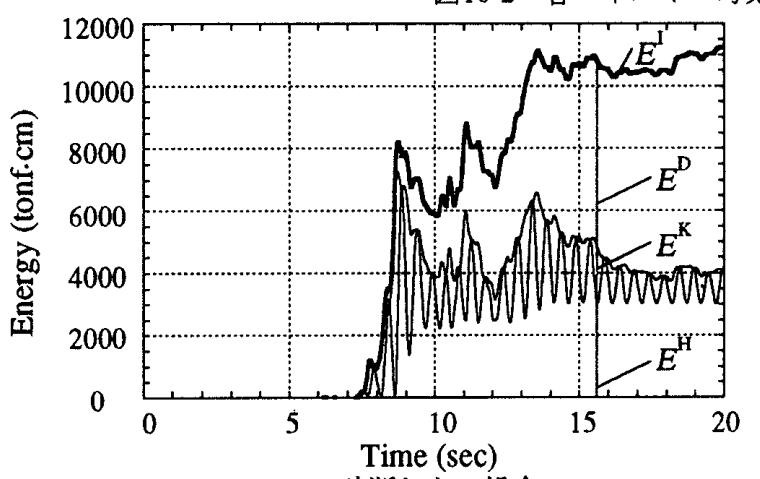

(a) 破断しない場合

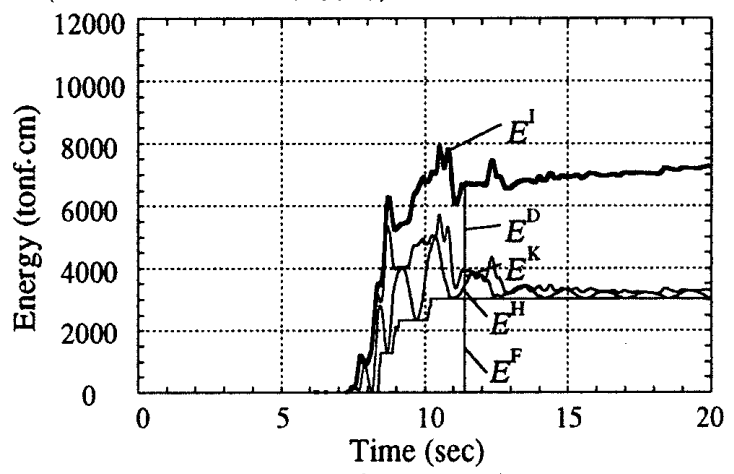

(b) 破断する場合

図10-3 各エネルギー時刻歴（Kobe 1995 NS 入力時）

\section{3. 5 柱端部最大曲げモーメント}

梁端部の脆性破壊の発生によって骨組が倒壊に対し てどの程度危険になるかを評価するには、応答中の柱 断面力の状態を調べることが重要である。Appendixに 梁端部と同様に柱端部も破断すると仮定した場合の解 析結果を示すが、この場合早期に層崩壊に至る。柱部 材は破断はもちろん塑性変形もさせない方が望ましい。

図11に、柱端部の最大曲げモーメントおよびモーメ ント比を示す。図(a)は破断しない場合の最大曲げモー メント（単位： $\times 10^{4}$ tonf $\cdot \mathrm{cm}$ ）を表す。值が 1 より小さ いとき○で表し、1より大きいときはので表すがのの 直径は值に応じて大きくした。図(b)は、破断する場合 の最大曲げモーメントの破断しない場合の最大曲げモー メント、すなわち図(a)、に対する比を表す。值が大き いものから約20カ所をので、その他を○で表す。破断
する場合は、破断しない場合に比べ、外側柱の柱端モー メントが大きくなる傾向があることが分かる。

3. 3.6 柱端部曲げモーメント〜軸力関係

外側柱は応答中の軸力変動が大きい。そこで本節で は、外側柱の曲げモーメント〜軸力関係を調べる。例 として、罒11(b)の(III)に示したKobeNS入力時に破断す る場合モーメントが比較的大きくなる、左側柱の 3 層 柱脚および 8 層柱頭について曲げモーメントと軸力の 関係を図12に示す。この部位は、図7-3(b)拉よび図8(b) から分かるように破断により層間変形角が大きくなる 領域の上下境界であり、柱の曲げ変形が大きくなると ころである。数値解析では柱の降伏モーメントを無限 大としたが、図12では作図上、降代応力 3.0 tonf $/ \mathrm{cm}^{2}$ の 理想化サンドイッチ断面を仮定した場合の降伏モーメ ントおよび降伏軸力で除すことにより正規化している。 


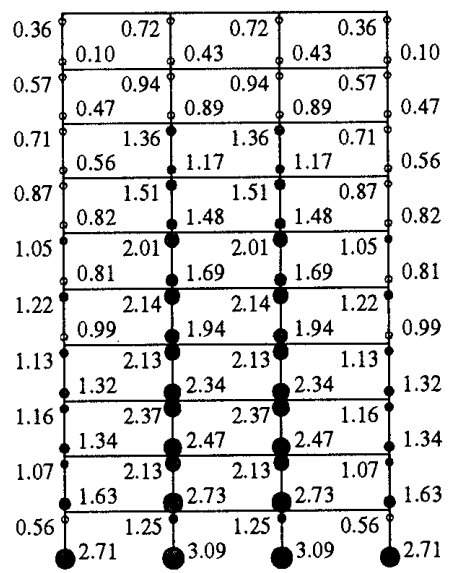

( I ) El Centro 1940 NS

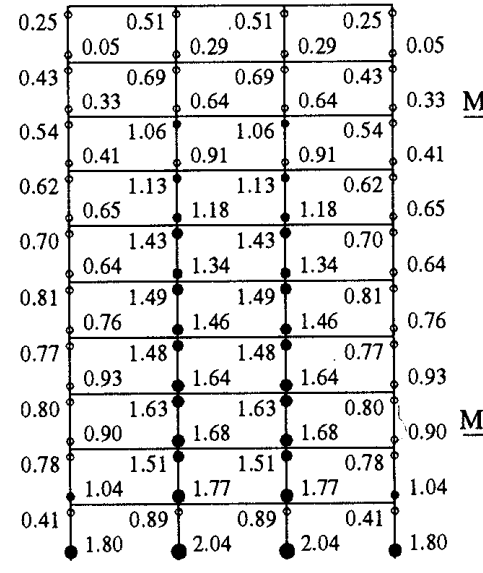

( II )Hachinohe 1968 NS

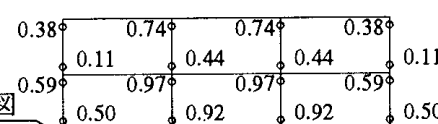
$0.844_{0.59}^{1.577_{1.21}^{0.92}}{ }_{1.21}^{0.844^{0.9}} 0.59$ $0.977^{0.59} 1.690^{1.21} 1.690 .210 .0 .59$

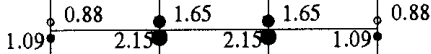
$1.210 .89 \frac{1.91}{2.19} \frac{1.91}{2.19}$ $1.05^{1.12} 2.08 \frac{2.12}{2.08} \underbrace{2.12} 1.05^{1.12}$ $1.03 \frac{1.41}{2.24} \frac{2.45}{2.24} 3^{2.45} 1.41$ $0.944_{1.97}^{1.37} \frac{2.48}{1.97}=0.948$ $0.499_{1.133}^{1.57} \underbrace{2.62}{ }^{2.62} 0.499^{1.57}$

(III) Kobe 1995 NS

図11(a) 柱端部最大曲げモーメント $\left(x 10^{4}\right.$ tonf $\left.\cdot \mathrm{cm}\right)$ ：破断しない場合

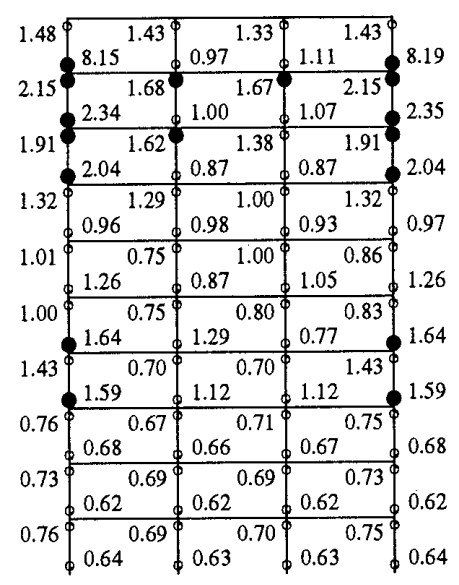

(I) El Centro 1940 NS

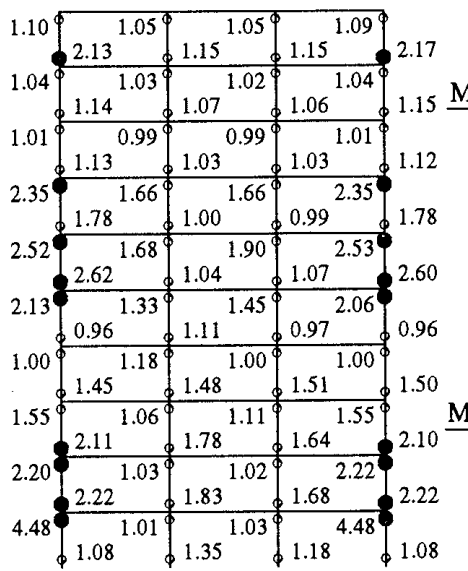

(II) Hachinohe $1968 \mathrm{NS}$

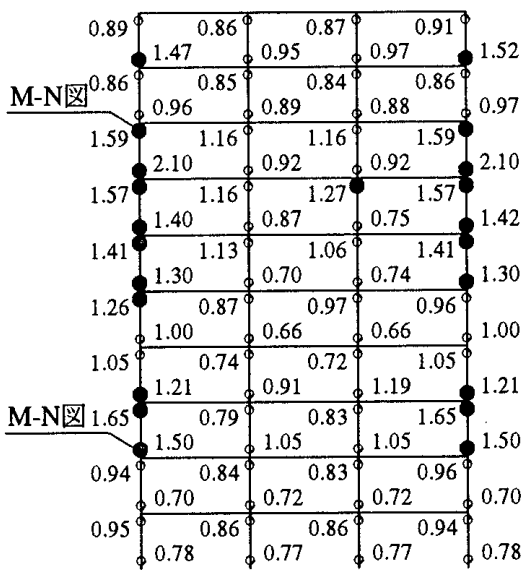

( III) Kobe 1995 NS

図11(b) 柱端部最大曲げモーメント比

破断する場合の最大曲げモーメント

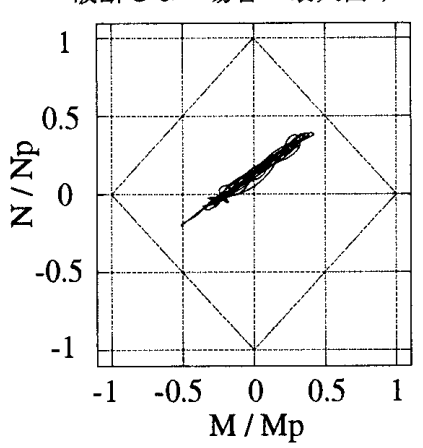

(a)破断しない場合

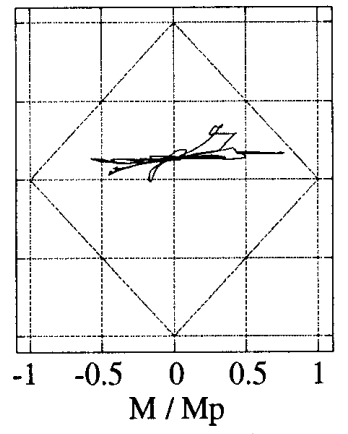

(b)破断する場合

図12(I) 左側柱 3 層柱脚部曲げモーメント〜軸力関係

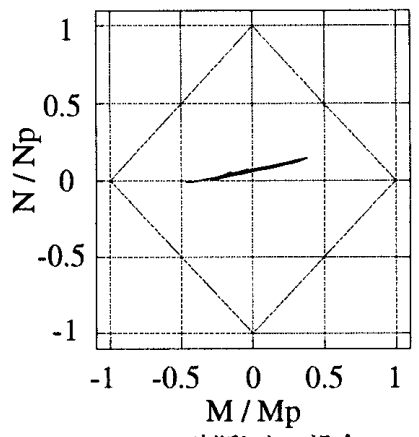

(a)破断しない場合

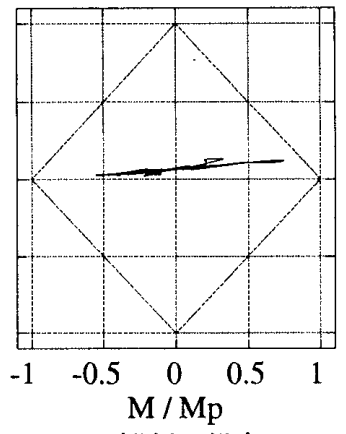

(b)破断する場合

図12(II) 左側柱 8 層柱頭部曲げモーメント〜軸力関係 


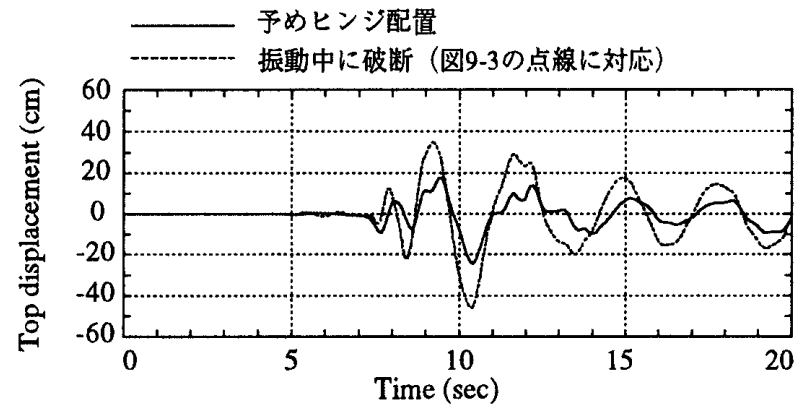

図13(a) 最上層水平変位時刻歴

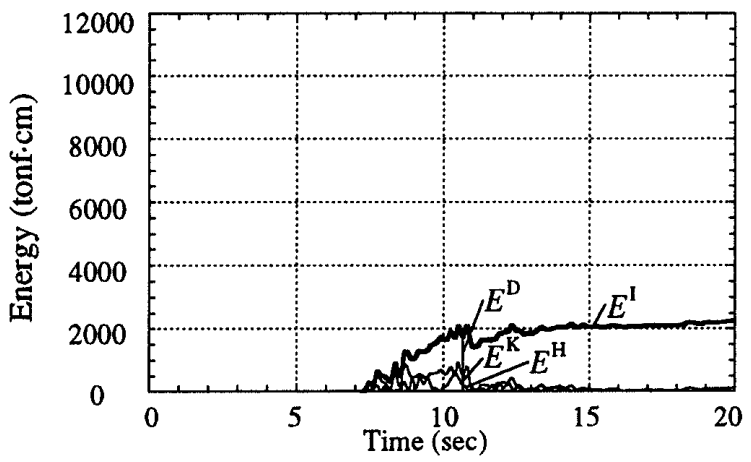

図13(b) 各エネルギー時刻歴：予めヒンジ配置

よりも振幅が小さい。図13(b)にエネルギー応答を示す。 図10-3(b)と比較して、予めヒンジを配固する場合の方 が、入力エネルギーがかなり少なく評価されている。

\section{2 考察}

予めヒンジを配置する場合、骨組の1 次固有周期が 最初から約 3 秒と長くなっており、このことが地震動 の入力エネルギーが実際に入力される量よりもかなり 少なく評価される原因になっていると考えられる。ま た一方では、地震動と骨組の組み合わせによっては、 逆に大きく評価されるケースも予想される。以上より、 予めヒンジを配置した骨組の地震応答解析を行うこと により、振動中に破断が生じる骨組の応答を推測する 方法は妥当ではないといえる。

\section{5. 結論}

想定した破断要素モデルが組み込まれた骨組モデル の動的応答を的確に追跡できる数值解析法を構筑した。 この解析法を用いて、振動中に梁端部が破断する10層3 スパン鋼構造骨組の地震応答を解析した。破断が応答 に及ぼす影響として以下の点を明らかにした。

（1）破断が生じないとしたモデル解析では、広範囲 に渡って塑性ヒンジが形成され、変形も全層に渡って 均一化する骨組においても、破断が生じるモデルでは、 特定の数層に破断部位が偏り、その結果それらの層に 変形が集中する。

（2）(a)破断時散逸エネルギーの総量が、破断が生じ ない場合の履歴消費エネルギーと同レベルに達する場 合がある。(b)破断が生じる場合の入力エネルギーは、 破断が生じない場合の入力エネルギーと比較して、大 きくなる場合もあれば小さくなる場合もある。(a),(b)い ずれの特性も、入力地震動特性に大きく影響を受ける。

（3）梁端部が破断する場合、外側柱の柱端曲げモー メントが大きくなるのに対し、軸力変動は小さくなる。

（4）破断が骨組応答に及ほす影響を評価するときに、 破断部位に予めヒンジを配置した骨組について応答解 析を行うと、振動中に破断が生じる骨組の応答とは全 く異なった結果を得ることになる。

\section{謝辞}

フジ夕技術研究所構造研究部主席研究員寺岡勝氏に は、有益なご意見や資料の提供をいただきました。こ こに深く感謝申し上げます。

\section{参考文献}

1) Bertero V. V. , Anderson J. C. and Krawinkler H. : Performance of steel building structure during the Northridge earthquake, Report No.UCB/EERC-94/09, Earthquake Research Center, August 1994

2）中島正愛：ノースリッジ地震に見る鉄骨接合部の被害, 建築技術，1994年9月号，pp.66-73.

3）山内泰之，向井昭義：S造の被害，建築技術，1995年8 月号, pp.90-93.

4）日本建築学会近畿支部鉄骨構造部会：1995年兵庫県南部 地震鉄骨造建物被害調査報告書, 1995年5月

5) 寺田岳彦, 坂本真一, 真瀨伸治, 岡澤岳：1995年兵庫県 南部地震における鉄骨造建物の地震時挙動と構造被害, 清水建設研究報告，第62号，pp.61-73，1995年10月

6) 寺岡勝，他 4 名：1995年兵庫県南部地震による 9 階建鉄 骨造建物の被害調査と検討（その1３），日本建築学 会大会学術講演梗概集，発表予定，1996年9月

7) 桑村仁，佐藤義也：強震を受ける柱降伏型多層骨組の脆 性連鎖崩壇，日本建築学会構造系論文集，第483号， pp.61-70，1996年5月.

8) 中村恒善: 骨組構造の解析, I滑組の非線形挙動の解析, (新建築学大系36巻) 4 章, pp.240-241, 彰国社, 1982.

9) Nigam, N.C. and Jennings, P.C. : Calculation of Response Spectra fromStrong Motion Earthquake Records, BSSA, Vol.59, No. 2, Apr. 1964, pp. 909-922.

10）加藤勉，森田耕次：極厚鋼部材の脆性破壊，日本建築学 会構造系論文報告集，第156号，pp.1-10，1969年2月．

11）加藤勉, 森田耕次, 橋本健一：極厚鋼部材の脆性破壊 （その 2)，日本建築学会構造系論文報告集，第176号， pp.11-16，1970年10月.

12）藤本盛久，他 4 名：柱はり溶接接合部の破壊特性の検討， 日本建築学会構造系論文報告集，第349号, pp.81-90， 1985年3月.

13）藤本盛久，他 4 名：柱はり溶接接合部の力学的性状抢よ 
び破壊に及ほす影響について，日本建築学会構造系論文 報告集，第357号，pp.81-88，1985年11月.

14）立山英二, 井上一朗, 杉本正三, 松村弘道：通しダイア フラム形式で角形鋼管柱に接合される $\mathrm{H}$ 形断面はりの耐 力と変形性能に関する研究，日本建築学会構造系論文報 告集，第389号，pp.109-121，1988年7月.

15）田渕基嗣，他 4 名：角形鋼管柱に接合される $\mathrm{H}$ 形鋼はり 端部の曲げ耐力の評価，日本建築学会構造系論文報告集， 第389号，pp.122-131，1988年7月。

16）中込忠男，青木博文：塑性歪を受けた構造用鋼材の力 学的性能に関する実験的研究, 構造工学論文集,

Vol.38B，pp.369-376，1992年3月.

17）立山英二, 井上一朗, 甲津功夫：現場溶接型のスカラッ プを設けた梁がH型鋼柱に接合される場合の塑性変形性 能に関する実験的研究，日本建築学会大会学術講演梗概 集C構造II, pp.1535-1536，1992年8月

18）中込忠男, 藤田哲也：角形鋼管柱に通しダイアフラム形 式で溶接接合される圧延 $\mathrm{H}$ 形鋼梁端部の力学的性能, 目 本建築学会構造系論文報告集, 第455号, pp.187-196, 1994年1月.

19）坂本真一, 矢部喜堂, 真瀬伸治 : 現場溶接接合形式の柱 梁接合部におけるH形鋼梁端部の力学的性能, 日本建築 学会構造系論文報告集，第456号，pp.69-79，1994年2月.

20）秋山宏，桑村仁，浅川達也，萩原行人：冷間プレス成形 角形鋼管溶接接合部の破壊特性, 日本建築学会構造系論 文報告集，第471号，pp.163-172，1995年5月。

21）田渕基嗣, 田中丈之：スカラップに起因する梁フランジ の脆性破断に関する研究，日本建築学会大会学術講演梗 概集C-1構造II, pp.543-544，1995年8月

22）上谷宏二，田川浩：梁端部下フランジの脆性破壊を伴う 鋼構造骨組の地震応答, 日本建築学会近畿支部研究報告 集, pp.181-184，1996年7月

23）大野茂，上谷宏二，田川浩：断面力に時刻歴不連続を生 じる平面骨組の動的挙動解析〜破断を生じる鋼構造骨組 の動的挙動特性, 日本建築学会大会学術講演梗概集, 発 表予定，1996年9月

24）上谷宏二，田川浩：梁端部の脆性破壊が鋼構造骨組の地 震応答に及㳆多影響, 第45回応用力学連合講演会予稿集, pp.107-108，1996年1月

\section{Appendix：柱端部の脆性破壊を考慮した数值応答解析}

ここでは、梁端部のみならず柱端部も破断すると仮定した ときの応答特性を明らかにする。

\section{A 1. 解析骨組}

図5に示した骨組を考える。部材断面は、本文中では柱の降 伏（破断）モーメントを無限大としたが、ここでは表A1に示 すように同一層の梁の降伏（破断）モーメントの1.5倍とする。 軸力は破断条件に考慮しない。

\section{A 2. 入力地震動}

入力地震動は、Kobe1995 NSの波形を最大速度振幅が50cm/ secとなるように基準化して用いる。いずれかの層の層間変形 角が0.05に達した時点で解析を䅂了する。
表A 1 部材断面諸量

\begin{tabular}{|c|c|c|c|c|}
\hline & $\begin{array}{l}\text { 断面 } 2 \text { 次モー } \\
\text { メント }\left(\mathrm{cm}^{4}\right)\end{array}$ & $\begin{array}{l}\text { 降伏 (破断) モーメ } \\
\text { ント (tonf } \cdot \mathrm{cm})\end{array}$ & $\begin{array}{r}\text { 断面積 } \\
\left(\mathrm{cm}^{2}\right) \\
\end{array}$ \\
\hline \multirow{4}{*}{ 柱 } & C1 & 200000 & 27000 & 400 \\
\hline & $\mathrm{C} 2$ & 160000 & 22500 & 350 \\
\hline & $\mathrm{C} 3$ & 120000 & 18000 & 300 \\
\hline & $\mathrm{C} 4$ & 80000 & 13500 & 250 \\
\hline \multirow{4}{*}{ 梁 } & G1 & 150000 & $-18 \underline{8} \underline{0} 00$ & \\
\hline & $\mathrm{G} 2$ & 120000 & 15000 & \\
\hline & G3 & 90000 & 12000 & \\
\hline & G4 & 60000 & 9000 & \\
\hline
\end{tabular}

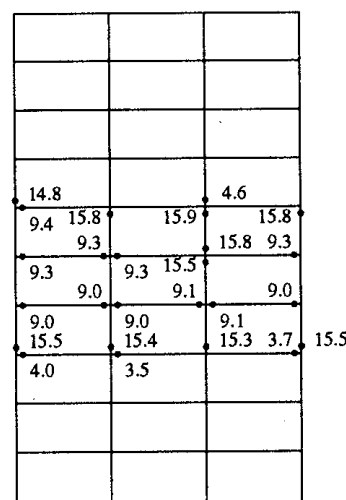

図A1 破断部位

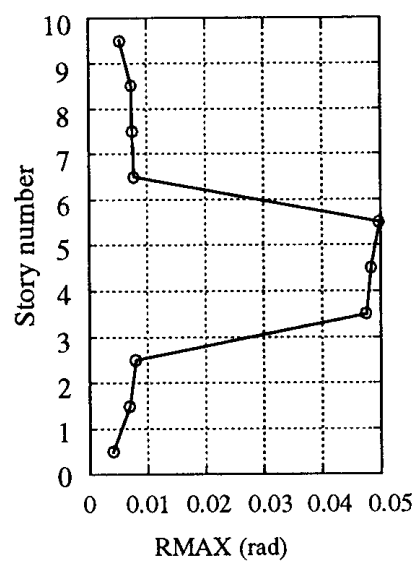

図A2 最大層間変形角

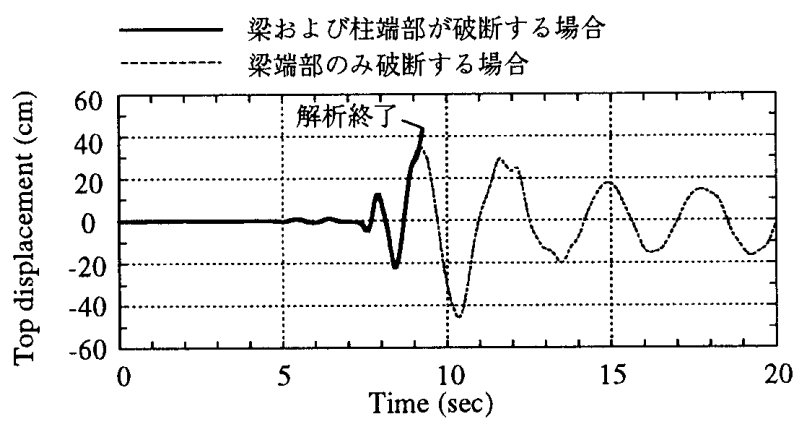

図 $\mathrm{A} 3$ 最上層水平変位時刻歴

\section{A 3. 解析結果}

A 3. 1 破断発生部位

図A１に破断が生じた部位を示す。4〜6層に破断が集中 して生じ、3 層に渡る層崩壊のメカニズムが形成されている。

A 3. 2 最大層間変形角

図A 2 に最大層間変形角を示す。メカニズムを形成した 4 〜 層の変形角が著しく大きくなっている。

A 3.3 頂点水平変位

図A 3 に頂点水平変位の時刻歴を示す。波線は、図9-3に示 した梁端部のみが破断する場合である。柱端部に破断が生じ る場合は極めて早期に崩壊に至ることが分かる。

A 4. 考察

最終的に層崩壤に至るが、その過程を細かく見ると、まず 
4, 5 層の梁端部が破断し、その層に変形が集中する。その 後、短時間に 4 層柱脚と 6 層柱頭で柱端部が破断し、メカニ ズムが形成し崩壊する。柱端部の破断が一カ所で生じると同 一高さの他の柱端部も続いて破断するのが特徴的である。
完全溶込み溶接された 10 層程度の銅構造骨組の被害では、 このような層崩哜は実際には見られなかったが、もし柱端部 が破断するようなことがあれば甚大な被害につながることが 考えられ、柱端部の破断が生じないように設計すべきである。 